\title{
Accumulation of heavy metals in leaf vegetables from agricultural soils and associated potential health risks in the Pearl River Delta, South China
}

\author{
C. Y. Chang • H. Y. Yu • J. J. Chen • F. B. Li • \\ H. H. Zhang $\cdot$ C. P. Liu
}

Received: 9 May 2013 / Accepted: 1 October 2013 / Published online: 3 November 2013

(C) The Author(s) 2013. This article is published with open access at Springerlink.com

\begin{abstract}
This study investigated the extent of heavy metal accumulation in leaf vegetables and associated potential health risks in agricultural areas of the Pearl River Delta (PRD), South China. Total concentrations of mercury $(\mathrm{Hg})$, cadmium $(\mathrm{Cd})$, lead $(\mathrm{Pb})$, chromium (Cr) and arsenic (As) were determined in 92 pairs of soil and leaf vegetable (flowering Chinese cabbage, lettuce, pakchoi, Chinese cabbage, loose-leaf lettuce, and Chinese leaf mustard) samples collected from seven agricultural areas (cities). The bioconcentration factors (BCF) of heavy metals from soil to vegetables were estimated, and the potential health risks of heavy metal exposure to the PRD residents through consumption of local leaf vegetables were assessed. Results showed that among the six leaf vegetables, pakchoi had the lowest capacity for heavy metal enrichment, whereas among the five heavy metals, Cd had the highest capacity for transferring from soil into vegetables, with $\mathrm{BCF}$ values 30 -fold those of $\mathrm{Hg}$
\end{abstract}

\section{Y. Chang}

Guangzhou Institute of Geochemistry, Chinese Academy of

Sciences, Guangzhou 510640, China

C. Y. Chang $\cdot$ H. Y. Yu • J. J. Chen • F. B. Li $(\bowtie) \cdot$

H. H. Zhang $\cdot$ C. P. Liu

Guangdong Public Laboratory of Environmental Science and Technology, Guangdong Institute of Eco-Environmental and Soil Sciences, Guangzhou 510650, China

e-mail: cefbli@soil.gd.cn

C. Y. Chang

Graduate University of Chinese Academy of Sciences,

Beijing 100049, China and 50-fold those of $\mathrm{Cr}, \mathrm{Pb}$ and As. Sewage irrigation and fertilization were likely the main sources of heavy metals accumulated in leaf vegetables grown in agricultural areas of the PRD region. Different from previous findings, soil $\mathrm{pH}$ had no clear effect on metal accumulation in leaf vegetables. Despite a certain degree of metal enrichment from soil to leaf vegetables, the PRD residents were not exposed to significant health risks associated with consumption of local leaf vegetables. Nevertheless, more attention should be paid to children due to their sensitivity to metal pollutants.

Keywords Pearl River Delta - Leaf vegetables · Heavy metals $\cdot$ Bioconcentration factor $\cdot$ Target hazard quotient

\section{Introduction}

Heavy metals can accumulate and migrate in soil environments. Due to their cumulative effects and long-term interactions, accumulation of heavy metals in soil negatively affects regional eco-safety and poses a threat to relevant animals and plants. Additionally, heavy metals can enter human bodies through the food chain, leading to an increased incidence of chronic diseases such as deformity and cancer (Müller and Anke 1994; Ramadan and Al-Ashkar 2007; Tembo et al. 2006). Studies have shown that fruit and vegetable consumption is the primary pathway of human exposure to heavy metals (Adamsa et al. 2004; McLaughlin et al. 1999). Therefore, it is of practical significance to assess the extent of heavy metal accumulation from soil into plants such as fruits and 
vegetables, and relevant research has gained increasing attentions.

The behaviors of metal in soils are very complex, which involve adsorption-desorption, complexationdissociation, oxidation-reduction, ion exchange, and other carrier transport role. The former two reactions mainly affect metal activity in soil, while oxidationreduction can also change metal valence (Swartjes et al. 2007). These chemical mechanisms can work together and affect one another, which formed a complex interaction system controlling metal fates. Heavy metals enter the vegetable tissues mainly through the roots and foliage, of which root uptake was the dominant pathway. Metals can be transferred from soil pore water into the plants though the roots in the form of dissolved ions (e.g., $\mathrm{Cd}^{2+}$ ) (McLaughlin et al. 2011). Series of complex processes occur in the soil pore water and crop rhizosphere.

The degree of metal enrichment in crops can be described with enrichment factor, which is defined as the ratio of a particular element content in a plant to that in soil. The concept of enrichment factor was first proposed by Zoller et al. (1974) for source diagnosis of atmospheric particulate matter in the Antarctic. In the following year, enrichment factor was used for investigating high-altitude atmospheric substances in the North Atlantic Ocean (Duce et al. 1975). Recently, the application of enrichment factor in the form of transfer factor, bioconcentration factor (BCF), and plant uptake factor has been expanded to research on soil, water system, and sediment, as well as assessment of heavy metal pollution in environmental geochemistry (Wang et al. 2006a, b; Khan et al. 2010; Brioschi et al. 2013; Delgado et al. 2012). In soil research, $\mathrm{BCF}$ is defined as the ratio of the content of a particular element in a plant to that in soil. BCF is an important quantitative indicator of crop contamination and has commonly been used for estimating metal transfer from soil into plants (García et al. 2009; Melgar et al. 2009; USEPA 2005). BCF-based research shows that the extent of metal enrichment in vegetables is highest in leaf vegetables, followed by tubers and fruit vegetables (Liu et al. 2012; Pandey and Pandey 2009). Regarding metal concentrations, cadmium $(\mathrm{Cd})$ and lead $(\mathrm{Pb})$ commonly occur at high levels in leaf vegetables while the $\mathrm{Zn}$ content of tubers is higher than other metal contents (Ngole 2011).

The bioavailability and toxicity of metals in soil are significantly influenced by $\mathrm{pH}$ condition (Badawy et al. 2002; Wang et al. 2006b). Soil pH is considered to be one of the most important factors that influence the transfer of
$\mathrm{Cd}$ and $\mathrm{Pb}$ from soil to plants, and higher $\mathrm{pH}$ values have been found to reduce the bioavailability and toxicity of $\mathrm{Cd}$ and $\mathrm{Pb}$ (McBride et al. 1997; Gray et al. 1999). There are many researchers who devote themselves to the research on the relation between soil $\mathrm{pH}$ and $\mathrm{Cd}$ uptake (Costa and Morel 1993; Hart et al. 2002; Kim et al. 2002; Tudorean and Phillips 2004; McLaughlin et al. 2011). The consistent conclusion is that the adsorption between soil particles and $\mathrm{Cd}$ increases with the increase of soil $\mathrm{pH}$, while Cd bioavailability decreased. The mechanism for this phenomenon can contribute to the increases of solubility and ion competition. As the soil $\mathrm{pH}$ decreases, the concentrations of $\mathrm{Fe}^{2+}, \mathrm{Mn}^{2+}, \mathrm{Zn}^{2+}$, and $\mathrm{Ca}^{2+}$ increase in soil solution, which enhance the competition of free ions and reduce the adsorption to soil particles (Tudorean and Phillips 2004). Additionally, Speir et al. (2003) reported that soil $\mathrm{pH}$ is the greatest determinant of the solubility and mobility of chromium $(\mathrm{Cr}), \mathrm{Pb}$ and $\mathrm{Zn}$ in a sandy soil. Due to the close relation between soil $\mathrm{pH}$ and heavy metal properties, correlation analysis of $\mathrm{pH}$ value and heavy metal accumulation is commonly applied in research on accumulation of heavy metal from soil to vegetables.

The Pearl River Delta (PRD) region in South China covers an area of $54,733 \mathrm{~km}^{2}$, with $13,357 \mathrm{~km}^{2}$ of agricultural land and $4,829 \mathrm{~km}^{2}$ of vegetable area (Fig. 1) (Guangdong Statistics Bureau 2012; Lu 1988). The PRD region is the largest vegetable production base in Guangdong Province and produced 11,291,987 tons of vegetable in 2011. It mainly exports to Hong Kong and Macao, which receive more than $50 \%$ of the total export volume of vegetables from the PRD (Guangdong Statistics Bureau 2012). Being one of the most developed regions in China, the PRD region has experienced substantial industrial pollution in recent decades. Associated soil and air pollution can enhance pollutant accumulation in vegetables, further increasing potential human health risks. However, previous studies on heavy metal accumulation in soil and/or vegetable in the PRD region were mainly focused on polluted soils in suburb, industrial or mining areas. Presently, there is a lack of report on heavy metal uptake by vegetables in large agricultural bases in the PRD region (Luo et al. 2011; Zhao et al. 2012).

To this end, the present study assessed the extent of heavy metal accumulation in leaf vegetables commonly grown in agricultural areas in the PRD region. Total concentrations of mercury $(\mathrm{Hg}), \mathrm{Cd}, \mathrm{Pb}, \mathrm{Cr}$ and arsenic (As) were determined in 92 pairs of leaf vegetable and soil samples. The accumulation of heavy metals in leaf 
vegetables was interpreted using $\mathrm{BCF}$, and the relation between $\mathrm{BCF}$ values and soil $\mathrm{pH}$ was examined by principal component analysis (PCA) and Pearson correlation analysis. The potential human health risks of heavy metal exposure to the PRD residents through consumption of local leaf vegetables were evaluated using the target hazard quotient (THQ). The results will provide reference data for further investigation of heavy metal accumulation in the PRD region, thereby improving the regional food safety.

\section{Materials and methods}

Soil and vegetable sampling and processing

Ninety-two pairs of soil and vegetable samples were collected in the PRD region during September-November 2011 (Fig. 1). The sampling locations were chosen from large vegetable bases and national basic farmland protection zones ( $>30 \mathrm{ha}$ ) distant from urban and industrial areas. Six kinds of leaf vegetables were collected during the harvest period, including flowering Chinese cabbage (Brassica campestris L. ssp. chinensis var. utilis Tsen et Lee), lettuce (Lactuca sativa L. var. romana Hort), pakchoi (Brassica chinensis L.), Chinese cabbage (Brassica pekinensis (Lour.) Rupr), loose-leaf lettuce (Lactuca sativa L.), and Chinese leaf mustard (Brassica juncea Coss). Soil samples were taken from the surface layer $(0-20 \mathrm{~cm})$ using a bamboo shovel and gently shaken off from the vegetables roots. All samples were sealed in polyethylene bags and transported to the laboratory within $6 \mathrm{~h}$ of collection.

The soil samples were air-dried at room temperature, with impurities manually removed. Then, the soils were ground and sieved through 80 meshes $(0.2 \mathrm{~mm})$. For vegetable samples, the decay and withered tissues were removed and the edible parts were washed with tap water to remove surface dirt. The edible parts of vegetables were repeatedly rinsed with deionized water and dried at $60{ }^{\circ} \mathrm{C}$ to a constant weight. The dry vegetable samples were crushed with a wooden hammer in a carnelian mortar and then passed through an 80-mesh sieve.

Heavy metal and soil $\mathrm{pH}$ analyses

The concentrations of heavy metals in soil and vegetable samples were determined according to the methods of Rasmussen et al. (1991). Briefly, $600 \mathrm{mg}$ of air-dried soil was mixed with $6 \mathrm{~mL}$ of concentrated $\mathrm{HNO}_{3}-$ $\mathrm{HClO}_{4}(87: 13, v / v)$ and $6 \mathrm{~mL}$ of concentrated $\mathrm{HCl}$. The mixture was digested and then dissolved in $2 \%$ $\mathrm{HCl}$ solution. The vegetable samples were digested in a mixture of $\mathrm{HNO}_{3}-\mathrm{HClO}_{4}-\mathrm{H}_{2} \mathrm{O}_{2}(87: 13: 10, v / v / v)$. The $\mathrm{Hg}$ and As concentrations of digestion solutions were determined using an atomic fluorescence morphological analyzer (SA-10, Titan, Beijing, China), $\mathrm{Pb}$ and $\mathrm{Cr}$ concentrations were determined using a WFX-130 flame atomic adsorption spectrophotometer (Braic, China), and the $\mathrm{Cd}$ content was determined using a Z-2700 graphite furnace atomic absorption spectrophotometer (Hitachi, Japan). Standard reference materials of soil samples (GBW 07418 and GBW07429 (GSS-15)) and citrus leaves (GBW10020 (GSB-11)) were assayed during sample analysis for quality control. Reagent blanks were included to ensure detection precision $(<5 \%)$. Soil $\mathrm{pH}$ was measured in soil slurries using a 1:2.5 soil-to-water ratio with a PHS-3C $\mathrm{pH}$ meter (Sartorius, China).

Data analyses

\section{BCF calculation}

BCF was calculated as follows:

$\mathrm{BCF}=\frac{C_{\text {vegetable }}}{C_{\text {soil }}}$

where $C_{\text {vegetable }}$ is the total concentration of a particular heavy metal in the vegetable $\left(\mathrm{mg} \mathrm{kg}^{-1} \mathrm{dw}\right)$, and $C_{\text {soil }}$ is the corresponding heavy metal concentration in the soil habitat of the vegetable $\left(\mathrm{mg} \mathrm{kg}^{-1}\right)$.

\section{Vegetable consumption-associated health risk assessment}

Potential health risks of heavy metal exposure to PRD residents through local leaf vegetable consumption were assessed using THQ that was first proposed by the United States Environmental Protection Agency (USEPA) for assessing the potential health risks of pollutant exposure to human health (USEPA 2002; Liu et al. 2006; Song et al. 2009; Wang et al. 2005). THQ is defined as the ratio of the body intake dose of a pollutant to the reference dose (Eqs. 1 and 2). If THQ> 1 , there will be a potential risk associated with this 
Fig. 1 Agricultural soil and leaf vegetable samplings locations in the Pearl River Delta region, South China (plus sign, flowering Chinese cabbage; diamond, lettuce; black circle, pakchoi; triangle, Chinese cabbage; white star, loose-leaf lettuce; black star, Chinese leaf mustard)
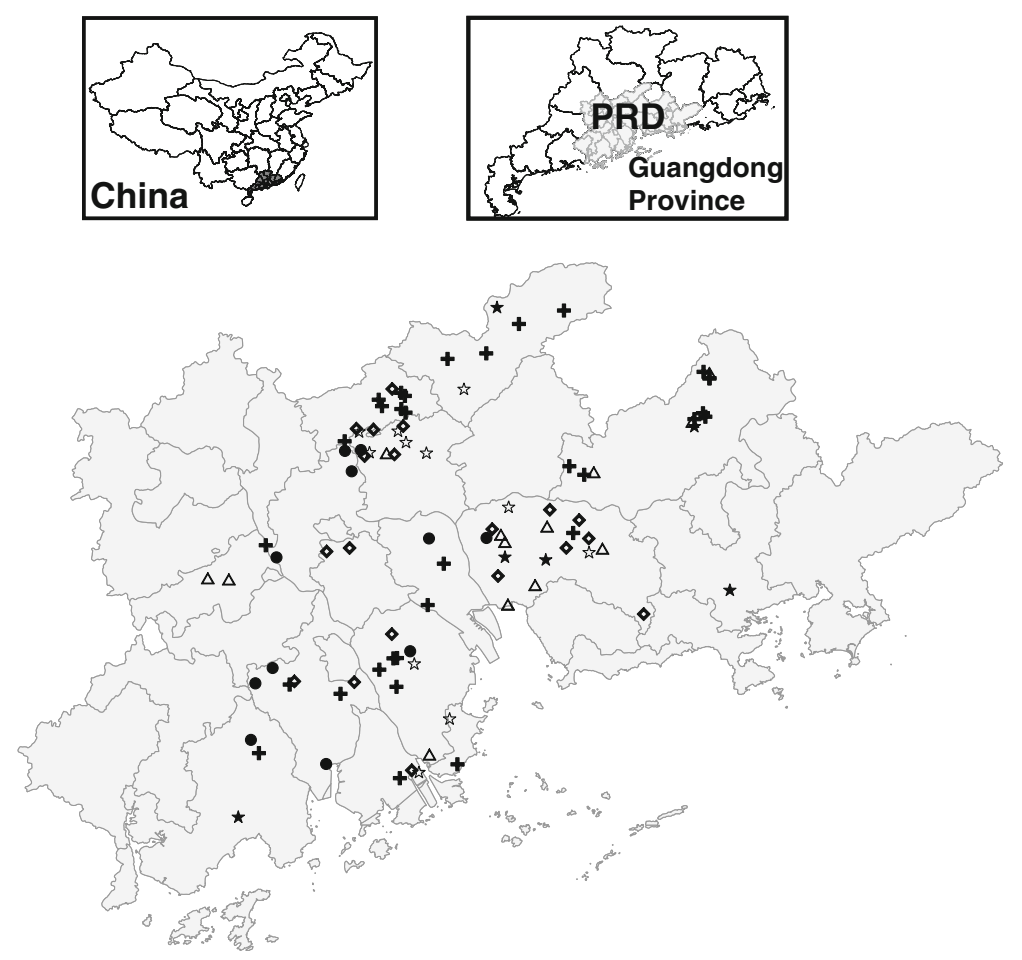

pollutant. If $\mathrm{THQ}<1$, there will be no obvious potential risk associated with this pollutant.

Single pollutant: $\quad \mathrm{THQ}=\frac{\mathrm{C} \times \mathrm{IR}_{\text {vegetable }} \times \mathrm{EF} \times \mathrm{ED}}{\mathrm{BW} \times \mathrm{AT} \times \mathrm{RfD}} \times 10^{-3}$

Total pollutants : $\quad \mathrm{THQ}_{\text {total }}=\sum \mathrm{THQ}_{\text {(single pollutant })}$

where $C$ is the mean concentration of a particular metal in a vegetable, IR is the daily vegetable intake by the PRD residents (including local and extraneous vegetables), EF is the exposure frequency (exposure days per year), ED is the exposure duration, BW is the average weight of local residents, AT is the average exposure time for non-carcinogens (exposure days within whole lifetime), and RfD is the reference dose. It must be noted that the present study concerns metal health risks due to the consumption of local leaf vegetables. Thus, parameters of fv (local vegetables/total vegetables consumption), fa (leaf vegetable/local vegetable), and $\mathrm{fb}$ (fruit vegetable/local vegetable) were introduced in the estimates of daily local leaf vegetable intake.

\section{Statistical analyses}

Statistical analyses were performed with the SPSS 13.0 software package. Charts and graphs were produced using Origin 8.1. The map of regional soil and vegetable sampling locations (Fig. 1) was constructed in ArcGis 10.0. The relation between BCF values of heavy metals in vegetables and associated soil $\mathrm{pH}$ was examined by Pearson correlation with the levels of significance at $P<$ 0.05 and $P<0.01$ (two-tailed) as well as PCA.

\section{Results and discussion}

Heavy metal distribution in agricultural soils and leaf vegetables in the PRD region

Total concentrations of $\mathrm{Hg}, \mathrm{Cd}, \mathrm{Pb}, \mathrm{Cr}$, and $\mathrm{As}$ in agricultural soils showed large variations in the PRD region (Table 1). In particular, the ranges of $\mathrm{Pb}, \mathrm{Cr}$, and As concentrations were $3.42-140,3.57-117$, and $0.68-105 \mathrm{mg} \mathrm{kg}^{-1}$, respectively. The average $\mathrm{Hg}, \mathrm{Cd}$, $\mathrm{Pb}$, and As concentrations of soil samples were higher than the background metal levels in Guangdong (Soil Survey Office of Guangdong Province 1993), whereas 


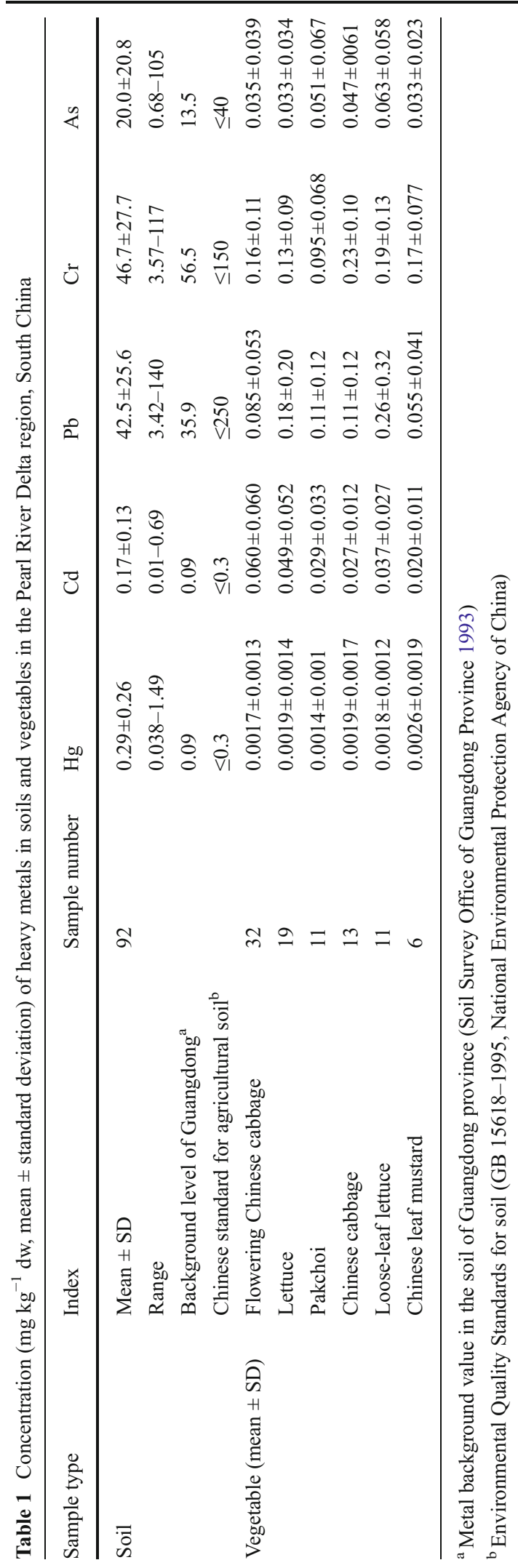

soil $\mathrm{Cr}$ concentration had no significant increases compared to the background $\mathrm{Cr}$ level in Guangdong (Table 1). Compared with the values in the Environmental Quality Standards for soil (GB 15618-1995, National Environmental Protection Agency of China), the mean soil $\mathrm{Pb}$ and $\mathrm{Cr}$ concentrations did not exceed the limits. Although the mean soil $\mathrm{Hg}, \mathrm{Cd}$, and As concentrations were below the national standard limits (Table 1), a few samples were moderately enriched with one or more than one of these heavy metals (19/92 for Hg, 11/92 for $\mathrm{Cd}$, and 10/92 for As). Overall, these results suggest that $\mathrm{Hg}, \mathrm{Cd}, \mathrm{Pb}$, and $\mathrm{As}$ were accumulated in agricultural soils in the PRD region.

Regarding regional distribution, Foshan and Zhongshan had relatively higher $\mathrm{Cd}, \mathrm{Pb}$, and $\mathrm{Cr}$ concentrations than other sampling areas (cities) in the PRD region (Fig. 2a). Among the seven cities, Jiangmen and Foshan had the highest average soil $\mathrm{Hg}$ concentration, whereas Huizhou had the highest average soil As concentration. The metal ( $\mathrm{Hg}, \mathrm{Cd}$, and $\mathrm{As})$ in some samples exceed the limit values recommended by the Environmental Quality Standards for soil (GB 15618-1995, National Environmental Protection Agency of China), while no samples contained $\mathrm{Pb}$ and $\mathrm{Cr}$ exceeding their limit values, respectively. The soil samples with excessive metals (Hg, Cd, and As) mainly came from Guangzhou (7/32), Zhongshan (4/8), and Huizhou (9/13), suggesting that more attention should be paid to $\mathrm{Hg}, \mathrm{Cd}$, and As pollution in Guangzhou, Zhongshan and Huizhou, respectively.

As compared to the soils, leaf vegetables contained less heavy metal contents with obvious variations among different species (Table 1). The ranges of vegetable $\mathrm{Pb}$ concentration were $0.009-0.22 \mathrm{mg} \mathrm{kg}^{-1}$ (flowering Chinese cabbage), $0.006-0.65 \mathrm{mg} \mathrm{kg}^{-1}$ (lettuce), $0.008-$ $0.37 \mathrm{mg} \mathrm{kg}^{-1}$ (pakchoi), $0.022-0.43 \mathrm{mg} \mathrm{kg}^{-1}$ (Chinese cabbage), $0.028-0.79 \mathrm{mg} \mathrm{kg}^{-1}$ (loose-leaf lettuce), and $0.008-0.13 \mathrm{mg} \mathrm{kg}^{-1}$ (Chinese leaf mustard), respectively. Of the 92 vegetable samples, there were 10 samples (11\%) containing excessive levels of $\mathrm{Pb}$ concentration $\left(0.3 \mathrm{mg} \mathrm{kg}^{-1}\right)$ and 27 samples (30\%) containing excessive levels of As $\left(0.05 \mathrm{mg} \mathrm{kg}^{-1}\right)$ referred to the Codex Alimentarius Commission (CAC) standard values. In contrast, the $\mathrm{Hg}, \mathrm{Cd}$ and $\mathrm{Cr}$ concentrations of all vegetable samples were below the CAC (FAO/WHO 2001) standard values $\left(0.01,0.2\right.$, and $0.5 \mathrm{mg} \mathrm{kg}^{-1}$, respectively). These results demonstrate that $\mathrm{Pb}$ and $\mathrm{As}$ are the dominant metal pollutants accumulated in leaf vegetables grown in agricultural soils in the PRD region. 


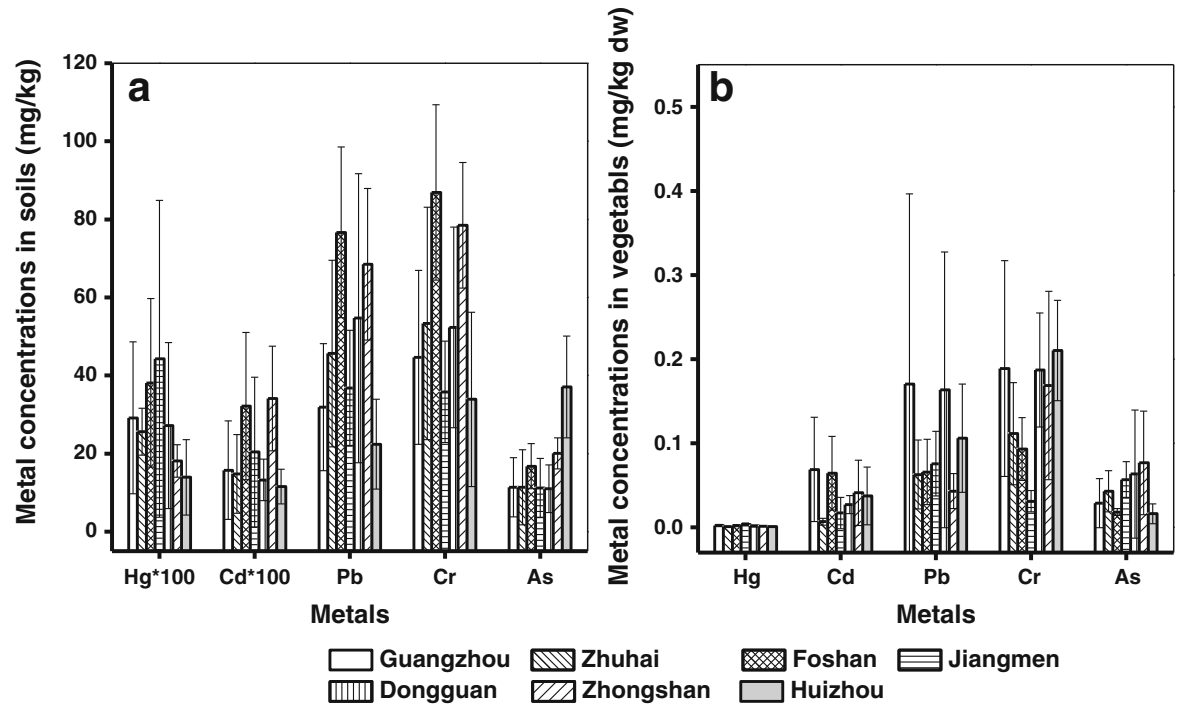

Fig. 2 Metal concentrations in soils (a) and vegetables (b) from different agricultural areas of the Pearl River Delta region, South China. The numbers of samples in Guangzhou, Zhuhai, Foshan,

Regarding regional distribution, the five metals accumulated in leafy vegetables showed different trends from those in soils. The vegetable samples with excessive levels of heavy metals (10/92 for $\mathrm{Pb}$ and 27/92 for As) were mainly from Guangzhou $(5 / 32$ for $\mathrm{Pb}$ and $5 / 32$ for As) and Dongguan (5/19 for $\mathrm{Pb}$ and 8/19 for As) (Fig. 2b), possibly due to the high degree of industrialization and relatively high pollutant concentrations in the atmosphere in these two cities (Wong et al. 2003). No vegetables with excessive levels of heavy metals were found in Foshan or Huizhou.

Bioaccumulation of heavy metals from soil to vegetables

The BCF values of $\mathrm{Hg}$ in vegetables ranged from 0.0005 to 0.0716 and averaged 0.010 , and those of $\mathrm{Pb}$, $\mathrm{Cr}$ and $\mathrm{As}$ in vegetables varied in similar ranges, i.e., $0.0001-0.0648,0.0002-0.027$, and 0.0001-0.103, respectively. By comparison, the $\mathrm{BCF}$ values of $\mathrm{Cd}$ in vegetables were significantly higher, varying from 0.010 to 3.10 and averaging 0.374 . The BCF values of $\mathrm{Cd}$ were approximately 30 -fold those of $\mathrm{Hg}$ and 50 -fold those of $\mathrm{Cr}, \mathrm{Pb}$ and As (Fig. 3). Since a greater BCF value indicates a higher accumulation potential of metals in vegetables (Chumbley and Unwin 1982; Cui et al. 2004), the above results indicate that $\mathrm{Cd}$ has higher capacity for transferring from soil to the edible parts of
Jiangmen, Dongguan, Zhongshan and Huizhou were 32, 5, 5, 10, 19,8 , and 13 , respectively

vegetables than the other four heavy metals in agricultural soil of the PRD region. This can be attributed to the competition between $\mathrm{Cd}^{2+}$ and $\mathrm{Ca}^{2+}$. It is easier for $\mathrm{Ca}^{2+}$ to be replaced by $\mathrm{Cd}^{2+}$ than other metals because of their same ionic radius and valence (Kim et al. 2002; Hart et al. 2002). In addition, $\mathrm{Ca}$ is an essential element for crops and it can enter plant tissues by active transport, while most heavy metals (as nonessential elements) can only enter plant tissues through passive methods (e.g., concentration diffusion and permeation) (Costa and

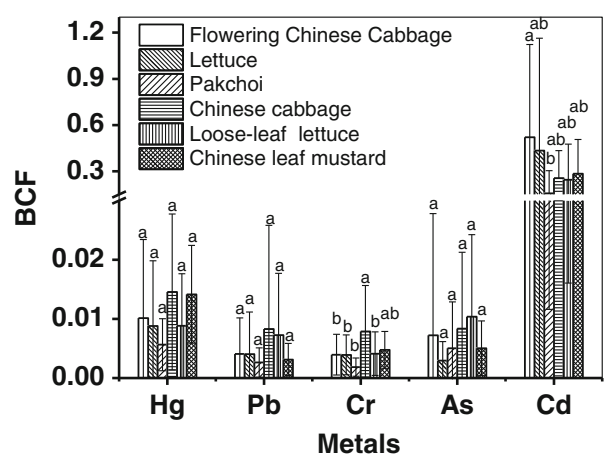

Fig. 3 Bioconcentration factor $(B C F)$ values of five heavy metals in six kinds of leaf vegetables collected from agricultural soils in the Pearl River Delta region, South China. Average value within the same treatment that has different lowercase letters (i.e., $a$ or $b$ ) is significantly different at $P<0.05$, whereas average value within the same treatment that has the same lowercase letters is not significantly different at $P=0.05$ 


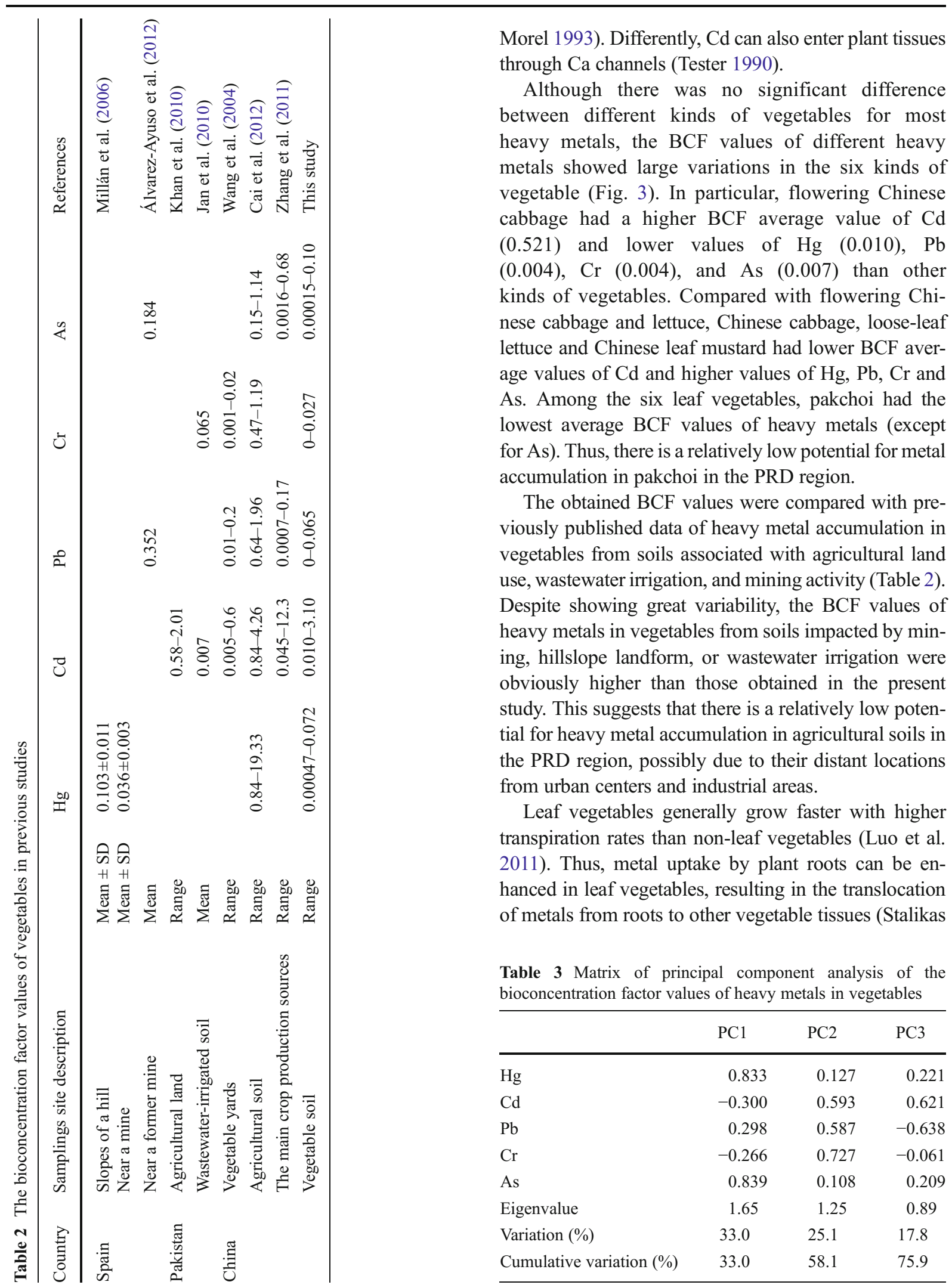


Table 4 Coefficients of correlations between soil $\mathrm{pH}$ and bioconcentration factor values

\begin{tabular}{lllllll}
\hline & Flowering Chinese cabbage & Lettuce & Pakchoi & Chinese cabbage & Loose-leaf lettuce & Chinese leaf mustard \\
\hline Sample number & 32 & 19 & 11 & 13 & 11 & 6 \\
$\mathrm{Hg}$ & $-0.412^{\mathrm{a}}$ & 0.156 & -0.374 & -0.370 & 0.448 & -0.193 \\
$\mathrm{Cd}$ & $0.371^{\mathrm{a}}$ & $0.533^{\mathrm{a}}$ & 0.222 & -0.267 & 0.307 & -0.690 \\
$\mathrm{~Pb}$ & 0.022 & 0.156 & -0.111 & 0.086 & $0.727^{\mathrm{a}}$ & -0.520 \\
$\mathrm{Cr}$ & 0.126 & $0.574^{\mathrm{a}}$ & 0.272 & 0.142 & 0.054 & 0.437 \\
$\mathrm{As}$ & $-0.476^{\mathrm{b}}$ & -0.174 & -0.304 & 0.191 & 0.290 & -0.648 \\
\hline
\end{tabular}

${ }^{\text {a }}$ Correlation is significant at the 0.05 level (two-tailed)

${ }^{\mathrm{b}}$ Correlation is significant at the 0.01 level (two-tailed)

et al. 1997; Zheng et al. 2007). Due to the broad leaf area, leaf vegetables are more susceptible to pollutant accumulation by the dust from soil and rainwater. To alleviate metal pollution in local vegetables, it is suggested to plant leaf vegetables in soil with low metal content and non-leaf vegetables in soil with relatively high metal content in large agricultural areas (Kucharski et al. 1994; Luo et al. 2011). According to results of the present study, pakchoi can be planted with priority in $\mathrm{Cd}$ enriched zones, followed by loose-leaf lettuce, Chinese cabbage, Chinese leaf mustard, lettuce and flowering Chinese cabbage. However, metal accumulation in vegetable tissues can be strongly influenced by multiple factors, including soil properties (e.g., soil $\mathrm{pH}$, organic matter, clay content and metal concentration), plant factors (e.g., plant type and panting mode), and other environmental conditions (e.g., atmosphere and industrial pollution) (Twining et al. 2004). Therefore, caution must be taken when making specific agricultural planting plans.

Identification of heavy metal sources

PCA has commonly been used for investigating metal sources, anthropogenic activities, or soil parent materials (Facchinelli et al. 2001; Loska and Wiechuła 2003; Borůvka et al. 2005; Cai et al. 2012). In the present study, three principal components (PC) were extracted from the BCF values of heavy metals in leaf vegetables (Table 3). The first principal component (PC1) explains $33.0 \%$ of the total variance and loaded heavily on $\mathrm{Hg}(0.833)$ and As (0.839). Studies have shown that average $\mathrm{Hg}$ concentration in wastewaterirrigated areas is approximately 6.9-fold the concentration of non-wastewater-irrigated area and that $\mathrm{Hg}$ contamination is serious in wastewater-irrigated agricultural soils in the PRD region (Zhu et al. 2005; Chen et al. 2005). Additionally, a study of $\mathrm{Hg}$ emission in Guangdong has shown that atmospheric $\mathrm{Hg}$ fluxes have no strong correlation with soil $\mathrm{Hg}$ concentration (Fu et al. 2012). Based on the above findings, we speculate that PC1 reflects the impacts of sewage irrigation.

The second principal component (PC2) accounts for $25.1 \%$ of the total variance and is dominated by $\mathrm{Cd}$ (0.593), $\mathrm{Pb}(0.587)$, and $\mathrm{Cr}(0.727)$. Because the mean soil $\mathrm{Cr}$ concentration $\left(46.7 \mathrm{mg} \mathrm{kg}^{-1}\right)$ was lower than the background level in Guangdong (56.5 mg kg${ }^{-1}$ ), the $\mathrm{Cr}$ accumulated in vegetables could mainly come from natural source(s). Based on $\mathrm{Pb}$ isotope analysis, Wong et al. (2002) reported that soil Pb in the PRD region mainly came from vehicle exhaust emissions. Whether the PC2 is derived from automobile exhaust emissions or natural source(s) in agricultural areas in the PRD region needs to be further investigated.

The third principal component (PC3) represents $17.8 \%$ of the total variance and is dominated by $\mathrm{Cd}$ (0.621) and negatively correlated with $\mathrm{Pb}(-0.638)$. Due to acidic soil $\mathrm{pH}$ condition and active phosphorus leaching, phosphate fertilizers are commonly used in the red-soil areas in the PRD region (Zhang and Ke 2004; Wong et al. 2002). Because phosphate fertilizers contain a large amount of $\mathrm{Cd}$, the application of phosphate fertilizers could result in substantial increases in the soil Cd concentration ( $\mathrm{Li}$ et al. 2004). Therefore, we assign the PC2 to a fertilizer source.

The effect of soil $\mathrm{pH}$ on heavy metal accumulation in vegetables

In target agricultural areas of the PRD region, soil $\mathrm{pH}$ ranged from 4.51 to 7.85 and averaged 6.31 (median, 6.45). Of the 92 soil samples, 63 had $\mathrm{pH}$ values less 
than 7.0. Results of frequency analysis of soil $\mathrm{pH}$ showed that there were $24,25,37$ and 6 soil samples with soil $\mathrm{pH}$ ranges of $<5.5,5.5-6.5,6.5-7.5$ and $>7.5$, respectively. Integrating these results indicates that the PRD agricultural soils was slightly to severely acidic.

Results of Pearson correlation analysis showed that there were significant correlations between soil $\mathrm{pH}$ and $\mathrm{BCF}$ values of $\mathrm{Hg}, \mathrm{Cd}$ and $\mathrm{As}$ but not $\mathrm{Pb}$ or $\mathrm{Cr}$ in flowering Chinese cabbage (Table 4). Thus, soil pH condition may play an important role in $\mathrm{Hg}, \mathrm{Cd}$ and $\mathrm{As}$ accumulation while showing minor or no effect on $\mathrm{Pb}$ and $\mathrm{Cr}$ uptake by flowering Chinese cabbage grown in agricultural areas in the PRD region. The BCF values of $\mathrm{Cd}$ and $\mathrm{Cr}$ in lettuce and the BCF values of $\mathrm{Pb}$ in loose-leaf lettuce were positively correlated to soil $\mathrm{pH}$ values ( $r=0.533,0.574$, and 0.727 , respectively; $P<$ $0.05)$. In contrast, the BCF values of the five metals in pakchoi, Chinese cabbage and Chinese leaf mustard had no correlations with soil $\mathrm{pH}$ values.

Our findings regarding the positive correlation between soil $\mathrm{pH}$ and the $\mathrm{BCF}$ value of $\mathrm{Cd}$ in flowering Chinese cabbage as well as lettuce in agricultural area of the PRD region are inconsistent with the conclusions of Zhao et al. (2009). Moreover, Dayton et al. (2006) reported that $\mathrm{pH}$ had no significant effect on the accumulation of $\mathrm{Pb}$ from soil into vegetables, while Zeng et al. (2011) showed that there was a significantly negative correlation between soil $\mathrm{pH}$ values and the EDTA-extractable $\mathrm{Cr}, \mathrm{Cu}, \mathrm{Fe}, \mathrm{Mn}, \mathrm{Pb}$ and $\mathrm{Zn}$ concentrations. Overall, the effect of $\mathrm{pH}$ on the availability of heavy metals in soil and their accumulation behaviors in vegetables has long been controversial (Wang et al. 2006a, b; Eriksson 1989; McBride 2002), which needs further investigations.

In addition to soil $\mathrm{pH}$ values, finer soil particles (clays) have a greater cation exchange capacity (CEC) and hence a greater ability to retain cationic metals than sandy soils. Soil organic matter (OM) plays an important role in affecting metal bioavailability in soils as $\mathrm{OM}$ is a major contributor to the $\mathrm{pH}$ dependent negative charge in soils which gives rise to the soils' ability to retain cationic metals (McLaughlin et al. 2011). Additionally, adsorption and complexation can also influence metal bioavailability in the soil. In the case of exogenous contamination, heavy metals are preferentially adsorbed and fixed in soil components with high specific surface areas, mainly oxides, clay minerals, and OM present in fine particles (Chen et al. 2009; McLaughlin et al. 2011). 
Table 6 Target hazard quotient values (mean \pm standard deviation) of heavy metals via vegetable consumption for the residents in the Pearl River Delta region, South China

\begin{tabular}{llllllll}
\hline & \multicolumn{2}{c}{$\mathrm{Hg}$} & $\mathrm{Cd}$ & $\mathrm{Pb}$ & $\mathrm{Cr}$ & As & Total THQ \\
\hline Flowering Chinese cabbage & Adult & $0.0026 \pm 0.0020$ & $0.028 \pm 0.028$ & $0.011 \pm 0.0071$ & $0.025 \pm 0.017$ & $0.055 \pm 0.061$ & $0.122 \pm 0.060$ \\
& Child & $0.0041 \pm 0.0031$ & $0.045 \pm 0.045$ & $0.018 \pm 0.011$ & $0.041 \pm 0.027$ & $0.088 \pm 0.097$ & $0.195 \pm 0.096$ \\
Lettuce & Adult & $0.0029 \pm 0.0021$ & $0.023 \pm 0.024$ & $0.023 \pm 0.027$ & $0.021 \pm 0.014$ & $0.051 \pm 0.052$ & $0.117 \pm 0.040$ \\
& Child & $0.0047 \pm 0.0034$ & $0.037 \pm 0.039$ & $0.038 \pm 0.043$ & $0.033 \pm 0.022$ & $0.082 \pm 0.084$ & $0.188 \pm 0.064$ \\
Pakchoi & Adult & $0.0022 \pm 0.0013$ & $0.013 \pm 0.015$ & $0.014 \pm 0.016$ & $0.015 \pm 0.011$ & $0.079 \pm 0.104$ & $0.124 \pm 0.117$ \\
& Child & $0.0036 \pm 0.0020$ & $0.022 \pm 0.025$ & $0.023 \pm 0.026$ & $0.024 \pm 0.017$ & $0.127 \pm 0.166$ & $0.198 \pm 0.188$ \\
Chinese cabbage & Adult & $0.0029 \pm 0.0027$ & $0.013 \pm 0.0055$ & $0.015 \pm 0.016$ & $0.036 \pm 0.016$ & $0.073 \pm 0.094$ & $0.140 \pm 0.111$ \\
& Child & $0.0047 \pm 0.0043$ & $0.020 \pm 0.0088$ & $0.024 \pm 0.025$ & $0.058 \pm 0.026$ & $0.117 \pm 0.151$ & $0.224 \pm 0.177$ \\
Loose-leaf lettuce & Adult & $0.0027 \pm 0.0019$ & $0.017 \pm 0.012$ & $0.035 \pm 0.043$ & $0.029 \pm 0.020$ & $0.098 \pm 0.090$ & $0.167 \pm 0.086$ \\
& Child & $0.0044 \pm 0.0030$ & $0.028 \pm 0.020$ & $0.056 \pm 0.069$ & $0.047 \pm 0.032$ & $0.157 \pm 0.143$ & $0.268 \pm 0.138$ \\
Chinese leaf mustard & Adult & $0.0040 \pm 0.0030$ & $0.0093 \pm 0.0053$ & $0.0073 \pm 0.0055$ & $0.027 \pm 0.0012$ & $0.051 \pm 0.035$ & $0.098 \pm 0.039$ \\
& Child & $0.0063 \pm 0.0048$ & $0.0015 \pm 0.0085$ & $0.012 \pm 0.0088$ & $0.043 \pm 0.019$ & $0.082 \pm 0.056$ & $0.158 \pm 0.063$ \\
Mean THQ of leaf & Adult & $0.0028 \pm 0.0021$ & $0.020 \pm 0.022$ & $0.017 \pm 0.021$ & $0.025 \pm 0.016$ & $0.065 \pm 0.073$ & $0.128 \pm 0.077$ \\
vegetables & Child & $0.0044 \pm 0.0033$ & $0.033 \pm 0.035$ & $0.027 \pm 0.033$ & $0.040 \pm 0.026$ & $0.104 \pm 0.117$ & $0.204 \pm 0.123$ \\
& & & & & & &
\end{tabular}

Potential health risk associated with consumption of leaf vegetables

The potential health risks were assessed using THQ, which were calculated according to Eqs 1 and 2. The parameters used in the equations were listed in Table 5.The potential health risk to local residents associated with vegetable consumption was assessed with the THQ index (Tables 6). Of the five heavy metals, As posed the greatest health risk to adults and children in the PRD study areas, followed by $\mathrm{Cr}$, $\mathrm{Cd}, \mathrm{Pb}$ and $\mathrm{Hg}(\mathrm{Hg}<\mathrm{Pb}<\mathrm{Cd}<\mathrm{Cr}<\mathrm{As}$ ) (Fig. 4a). For both children and adults, the THQs of heavy metals in the

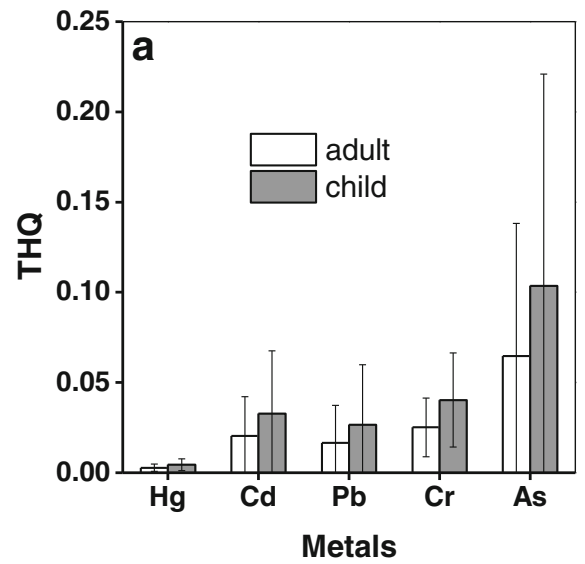

six leaf vegetables were less than 1.0 (Table 6), indicating that the residents in the PRD region were not exposed to significant health risks associated with consumption of local leaf vegetables. In addition, the health risks of heavy metal exposure to PRD residents varied in different leaf vegetables. Of the five metals, $\mathrm{Hg}$ and $\mathrm{Cr}$ had the lowest THQs in pakchoi, whereas the other metals $(\mathrm{Cd}, \mathrm{Pb}$ and As) had the lowest THQ values in Chinese leaf mustard. In the six kinds of leaf vegetables, the THQs of $\mathrm{Hg}, \mathrm{Cd}, \mathrm{Pb}$, $\mathrm{Cr}$ and As were highest in Chinese leaf mustard, flowering Chinese cabbage, loose-leaf lettuce, Chinese cabbage and loose-leaf lettuce, respectively (Table 6).

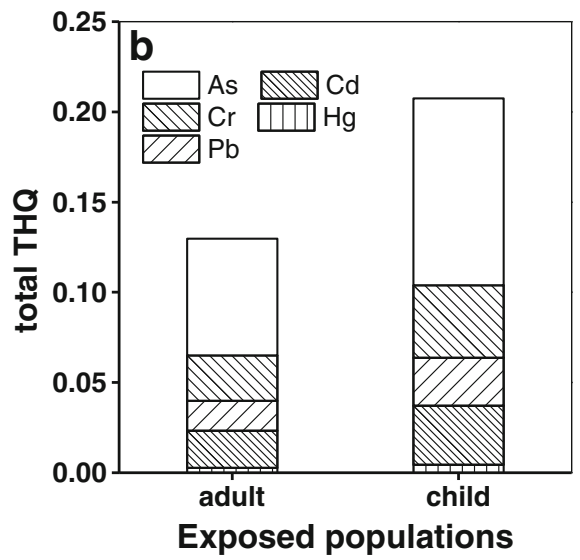

Fig. 4 The target hazard quotient (THQ) (a) and total THQ (b) of five heavy metals to children and adults via vegetable consumption in the Pearl River Delta region, South China 
The total THQs of health risk to children and adults in the PRD region with consumption of leaf vegetables were 0.208 and 0.130 , respectively (Fig. 4b). Thus, the residents in the PRD region were exposed to minimal risks associated with consumption of leaf vegetable. Although the children's average daily intake of vegetable only accounts for $72.4 \%$ of the adults' intake, the total THQ of heavy metals for children was approximately 1.6-fold that for adult. Thus, the children are more sensitive to heavy metal exposure through local vegetable consumption than adults in agricultural areas in the PRD region.

The THQ values of $\mathrm{As}, \mathrm{Cr}, \mathrm{Cd}$, and $\mathrm{Pb}$ accounted for $50.1,19.3,16.0$, and $12.4 \%$ of the total THQs, respectively, while that of $\mathrm{Hg}$ accounted for a small portion only, $\sim 2.17 \%$. These results indicate that As, $\mathrm{Cr}, \mathrm{Cd}$ and $\mathrm{Pb}$ primarily impose health risks to the resident in the study area, while $\mathrm{Hg}$ has a minor contribution to human health risks. The total THQs of metals in leaf vegetables for children and adults in the PRD region (0.208 and 0.130) were far below those of market vegetables in Chongqing where even a single metal's THQ has exceeded the total THQ (e.g., THQ of $\mathrm{Pb}$ for adults were 0.45-0.52) (Yang et al. 2011) and Beijing (0.771 and 0.605) (Song et al. 2009).

It should be noted that the present study only estimated the health risk of heavy metals to the residents via consumption of local leaf vegetables, which accounts for $70 \%$ of total vegetable consumption in the PRD region. That is, this work only takes into account part but not the total risks to PRD residents associated with consumption of vegetables. In addition, the total risks of heavy metals are related to the main polluted metals, and their long-term interactions which can impose distinct ecological or health risks via antagonistic, additive, and/or synergistic effects (Menzie et al. 2009; Nordberg et al. 2005) were not considered. Thus, the potential health risks of heavy metal exposure to local residents through consumption of leaf vegetables might be underestimated.

\section{Conclusions}

In the agricultural areas of the PRD region, pakchoi had the lowest capacity for metal enrichment among the six leaf vegetables under study. Of the five heavy metals, Cd was more easily transferred from soil unto leaf vegetables, with $\mathrm{BCFs} \sim 30$-fold those of $\mathrm{Hg}$ and 50 -fold those of $\mathrm{Cr}, \mathrm{Pb}$ and As. The main metal sources for leaf vegetables in the PRD agricultural areas might include sewage irrigation and chemical fertilization. Despite the significant correlation between $\mathrm{BCF}$ and soil $\mathrm{pH}$ values in specific samples, there is no clear relationship between these two parameters in all samples as a whole. The characteristics of heavy metal accumulation in crops and associated agricultural soil conditions need to be comprehensively considered for appropriate formulation of agricultural planting plans. Despite a certain degree of metal enrichment in soils and vegetables, the PRD residents were not experiencing significant health risk of heavy metal exposure through consumption of local leaf vegetables in agricultural areas. Still, more attentions should be paid to children due to their higher sensitivity to heavy metal exposure than that of adults.

Acknowledgments The research was financially supported by the National Natural Science Foundation of China (no. 31270546 and no. 41171387), the Guangzhou Municipal Technology Support Program (no. 2012J2200004), the Guangdong Provincial Research \& Development Project (no. 2011B030900004 and no. 2011B030900013), the Science and Technology Planning Project of Guangzhou (no. 2013J2200003), and Natural Science Foundation of Guangdong province (no. S2011010006107 and no. S2011040001105).

Open Access This article is distributed under the terms of the Creative Commons Attribution License which permits any use, distribution, and reproduction in any medium, provided the original author(s) and the source are credited.

\section{References}

Adamsa, M. L., Zhao, F. J., McGratha, S. P., Nicholsonb, F. A., \& Chambersb, B. J. (2004). Predicting cadmium concentrations in wheat and barley grain using soil properties. Journal of Environmental Quality, 33, 532-541.

Álvarez-Ayuso, E., Otones, V., Murciego, A., García-Sánchez, A., \& Regina, I. S. (2012). Antimony, arsenic and lead distribution in soils and plants of an agricultural area impacted by former mining activities. Science of the Total Environment, 439, 35-43.

Badawy, S. H., Helal, M. I. D., Chaudri, A. M., Lawlor, K., \& McGrath, S. P. (2002). Soil solid-phase controls lead activity in soil solution. Journal of Environmental Quality, 31, 162-167.

Baes, C. F., III, Sharp, R. D., Sjoreen, A. L., \& Shor, R. W. (1984). A review and analysis of parameters for assessing transport of environmentally released radionuclides through agriculture. Oak Ridge: Oak Ridge National Laboratory.

Bennett, D., Kastenberg, W., \& McKone, T. (1999). A multimedia, multiple pathway risk assessment of atrazine: the impact of age differentiated exposure including joint uncertainty and variability. Reliab Eng Syst Safe, 63, 185-198. 
Borůvka, L., Vacek, O. \& Jehlička, J., (2005). Principal component analysis as a tool to indicate the origin of potentially toxic elements in soils. Geoderma, 128(3-4), 289-300.

Brioschi, L., Steinmann, M., Lucot, E., Pierret, M. C., Stille, P., Prunier, J., \& Badot, P. M. (2013). Transfer of rare earth elements (REE) from natural soil to plant systems: implications for the environmental availability of anthropogenic REE. Plant and Soil, 366, 143-163. doi:10.1007/s11104-012-1407-0.

Cai, L. M., Xu, Z. C., Ren, M. Z., Guo, Q. W., Hu, X. B., Hu, G. C., Wan, H. F., \& Peng, P. G. (2012). Source identification of eight hazardous heavy metals in agricultural soils of Huizhou, Guangdong Province, China. Ecotoxicology and Environmental Safety, 78, 2-8.

Chen, Y. J., Wen, Y. M., \& Chai, S. W. (2005). The heavy metal content character of agricultural soil in the Pearl River Delta. Acta Scientiae Circumstantiae, 18(3), 75-77,87.

Chen, T., Liu, X. M., Li, X., Zhao, K. L., Zhang, J. B., Xu, J. M., Shi, J. C., \& Dahlgren, R. A. (2009). Heavy metal sources identification and sampling uncertainty analysis in a fieldscale vegetable soil of Hangzhou, China. Environmental Pollution, 157(3), 1003-1010.

Chumbley, C. G., \& Unwin, R. J. (1982). Cadmium and lead content of vegetable crops grown on land with a history of sewage sludge application. Environmental Pollution Series B, Chemical and Physical, 4(3), 231-237.

Costa, G., \& Morel, J. L. (1993). Cadmium uptake by Lupinus albus (L): cadmium excretion, a possible mechanism of cadmium tolerance. Journal of Plant Nutrition, 16(10), 1921-1929.

Cui, Y. J., Zhu, Y. G., Zhai, R. H., Chen, D. Y., Huang, Y. Z., Qiu, Y., \& Liang, J. Z. (2004). Transfer of metals from soil to vegetables in an area near a smelter in Nanning, China. Environment International, 30(6), 785-791.

Dayton, E. A., Basta, N. T., Payton, M. E., Bradham, K. D., Schroder, J. L., \& Lamno, R. P. (2006). Evaluating the contribution of soil properties to modifying lead phytoavailability and phytotoxicity. Environmental Toxicology Chemistry, 25, 719-725.

Delgado, J., Pérez-López, R., Galván, L., Nieto, J. M., \& Boski, T. (2012). Enrichment of rare earth elements as environmental tracers of contamination by acid mine drainage in salt marshes: a new perspective. Marine Pollution Bulletin, 64(9), 1799-1808.

Duce, R., Hoffmann, G. L., \& Zoller, W. H. (1975). Atmospheric trace metals at remote northern and southern hemisphere sites: pollution or natural? Science, 187, 59-61.

Eriksson, J. E. (1989). The influence of $\mathrm{pH}$, soil type and time on adsorption and uptake by plants of $\mathrm{Cd}$ added to the soil. Water, Air, and Soil Pollution, 48, 317-335.

Facchinelli, A., Sacchi, E., \& Mallen, L. (2001). Multivariate statistical and GIS-based approach to identify heavy metal sources in soils. Environmental Pollution, 114 (3): 313324.

FAO/WHO. (2001). Joint FAO/WHO food standards programme - Codex Alimentarius Commission. Report of the $33 \mathrm{rd}$ session of the codex committee on food additives and contaminants. the Netherlands: The Hague.

Fu, X. W., Feng, X. B., Zhang, H., Yu, B., \& Chen, L. G. (2012). Mercury emissions from natural surfaces highly impacted by human activities in Guangzhou province, South China. Atmospheric Environment, 54, 185-193.

García, M. Á., Alonso, J., \& Melgar, M. J. (2009). Lead in edible mushrooms: levels and bioaccumulation factors. Journal of Hazardous Materials, 167(1-3), 777-783.
Gray, C. W., McLaren, R. G., Roberts, A. H. C., \& Condron, L. M. (1999). Cadmium phytoavailability in some New Zealand soils. Soil Research, 37(3), 461-478.

Guangdong Statistics Bureau. (2012). Statistical yearbook of Guangdong, China. Beijing: China Statistics.

Hart, J. J., Welch, R. M., \& Norvell, W. A. (2002). Transport interaction between $\mathrm{Cd}$ and $\mathrm{Zn}$ in roots of bread wheat and durum wheat seedlings. Physiologia Plantarum, 116(1), 73-78.

Jan, F. A., Ishaq, M., Khan, S., Ihsanullah, I., Iahmad, I., \& Shakirullah, M. (2010). A comparative study of human health risks via consumption of food crops grown on wastewater irrigated soil (Peshawar) and relatively clean water irrigated soil (lower Dir). Journal of Hazardous Materials, 179(1-3), 612-621.

Khan, S., Rehman, S., Zeb Khan, A., Amjad Khan, M., \& Tahir Shah, M. (2010). Soil and vegetables enrichment with heavy metals from geological sources in Gilgit, northern Pakistan. Ecotoxicology and Environmental Safety, 73(7), 1820-1827.

Kim, Y.Y., Yang, Y.Y. \& Lee, Y., (2002). Pb and Cd uptake in rice roots. Physiologia Plantarum, (116):368-372.

Kucharski, R., Marchwińska, E., \& Gzyl, J. (1994). Agricultural policy in polluted areas. Ecological Engineering, 3(3), 299-312.

Li, X., Lee, S. I., Wong, S. C., Shi, W., \& Thornton, I. (2004). The study of metal contamination in urban soils of Hong Kong using a GIS-based approach. Environmental Pollution, 129(1), 113-124.

Liu, C. W., Liang, C. P., Huang, F. M., \& Hsueh, Y. M. (2006). Assessing the human health risks from exposure of inorganic arsenic through oyster (Crassostrea gigas) consumption in Taiwan. Science of the Total Environment, 361(1-3), 57-66.

Liu, L., Hu, L. L., Tang, J. J., Li, Y. F., Zhang, Q., \& Chen, X. (2012). Food safety assessment of planting patterns of four vegetabletype crops grown in soil contaminated by electronic waste activities. Journal of Environmental Management, 93(1), 22-30.

Loska, K., \& Wiechuła, D. (2003). Application of principal component analysis for the estimation of source of heavy metal contamination in surface sediments from the Rybnik Reservoir. Chemosphere, 51(8), 723-733.

Lu, F. X. (1988). The Pearl River Delta soil. Beijing: China Environmental Science.

Luo, C. L., Liu, C. P., Wang, Y., Liu, X., Li, F. B., Zhang, C., \& Li, X. D. (2011). Heavy metal contamination in soils and vegetables near an e-waste processing site, south China. Journal of Hazardous Materials, 186(1), 481-490.

Ma, W.J., Deng, F., Xu, Y,J., Xu, H.F., Nie, S.P., Li, J.S., Deng, H.H. \& Li, H.K., (2005). The study on dietary intake and nutritional status of residents in Guangdong. Guangdong Journal of Health and Epidemic Prevention 31(1): 1-5.

McBride, M. (2002). Cadmium uptake by crops estimated from soil total Cd and pH. Soil Science, 167(1), 62-67.

McBride, M., Sauve, S., \& Hendershot, W. (1997). Solubility control of $\mathrm{Cu}, \mathrm{Zn}, \mathrm{Cd}$ and $\mathrm{Pb}$ in contaminated soils. European Journal of Soil Science, 48(2), 337-346.

McLaughlin, M. J., Parker, D. R., \& Clarke, J. M. (1999). Metals and micronutrients - food safety issues. Field Crops Research, 60(1-2), 143-163.

McLaughlin, M. J., Smolders, E., Degryse, F., \& Rietra, R. (2011). Uptake of metals from soil into vegetables. In F. A. Swartjes (Ed.), Dealing with contaminated sites: from theory towards practical application. Heidelberg: Springer. doi:10.1007/978-90-481-9757-6 8 . 
Melgar, M. J., Alonso, J., \& García, M. A. (2009). Mercury in edible mushrooms and underlying soil: bioconcentration factors and toxicological risk. Science of the Total Environment, 407(20), 5328-5334.

Menzie, C. A., Ziccardi, L. M., Lowney, Y. W., Fairbrother, A., Shock, S. S., Tsuji, J. S., Hamai, D., Proctor, D., Henry, E., Su, S. H., Kierski, M. W., Mcardle, M. E., \& Yost, L. J. (2009). Importance of considering the framework principles in risk assessment for metals. Environmental Science and Technology, 43(22), 8478-8482.

Millán, R., Gamarra, R., Schmid, T., Sierra, M. J., Quejido, A. J., Sánchez, D. M., Cardona, A. I., Fernández, M., \& Vera, R. (2006). Mercury content in vegetation and soils of the Almadén mining area (Spain). Science of the Total Environment, 368(1), 79-87.

Müller, M., \& Anke, M. (1994). Distribution of cadmium in the food chain (soil-plant-human) of a cadmium exposed area and the health risks of the general population. Science of the Total Environment, 156(2), 151-158.

Ngole, V. M. (2011). Using soil heavy metal enrichment and mobility factors to determine potential uptake by vegetables. Plant, Soil and Environment, 57(2), 75-80.

Nordberg, G. F., Jin, T., Hong, F., Zhang, A., Buchet, J. P., \& Bernard, A. (2005). Biomarkers of cadmium and arsenic interactions. Toxicology and Applied Pharmacology, 206(2), 191-197.

Pandey, J., \& Pandey, U. (2009). Accumulation of heavy metals in dietary vegetables and cultivated soil horizon in organic farming system in relation to atmospheric deposition in a seasonally dry tropical region of India. Environmental Monitoring and Assessment, 148(1-4), 61-74.

Ramadan, M. A. E., \& Al-Ashkar, E. A. (2007). The effect of different fertilizers on the heavy metals in soil and tomato plant. Australian Journal of Basic and Applied, 1, 300306.

Rasmussen, P., Mierle, G., \& Nriagu, J. (1991). The analysis of vegetation for total mercury. Water, Air, \& Soil Pollution, 56(1), 379-390.

Soil Survey Office of Guangdong Province. (1993). Guangdong soils (pp. 621-622). Beijing: Science Press.

Song, B., Lei, M., Chen, T. B., Zheng, Y. M., Xie, Y. F., Li, X. Y., $\&$ Gao, D. (2009). Assessing the health risk of heavy metals in vegetables to the general population in Beijing, China. Journal of Environmental Sciences, 21(12), 1702-1709.

Speir, T. W., Van Schaik, A. P., Percival, H. J., Close, M. E., \& Pang, L. P. (2003). Heavy metals in soil, plants and groundwater following high-rate sewage sludge application to land. Water, Air, and Soil Pollution, 150, 319-358.

Stalikas, C. D., Chaidou, C. I., \& Pilidis, G. A. (1997). Enrichment of PAHs and heavy metals in soils in the vicinity of the lignite-fired power plants of West Macedonia (Greece). Science of the Total Environment, 204(2), 135-146.

Swartjes, F. A., Breemen, E. M. D., Otte, P. F., Beelen, P. V., Rikken, M. G. J., \& Tuinstra, J. (2007). Human health risks due to consumption of vegetables from contaminated sites. RIVM report 71101040 . Bilthoven: National Institute for Public Health and the Environment.

Tembo, B. D., Sichilongo, K., \& Cernak, J. (2006). Distribution of copper, lead, cadmium and zinc concentrations in soils around Kabwe town in Zambia. Chemosphere, 63(3), 497-501.

Tester, M. (1990). Plant ion channels: whole-cell and singlechannel studies. New Phytologist, 114(3), 305-340.
Tudorean, L., \& Phillips, C. J. C. (2004). Modeling cadmium uptake and accumulation in plants. Advances in Agronomy, 84, 121-157.

Twining, J. R., Payne, T. E., \& Itakura, T. (2004). Soil-water distribution coefficients and plant transfer factors for $134 \mathrm{Cs}, 85 \mathrm{Sr}$ and $65 \mathrm{Zn}$ under field conditions in tropical Australia. Journal of Environmental Radioactivity, 71(1), 71-87.

U.S. Environmental Protection Agency (USEPA). (2002). Region 9 , preliminary remediation goals. http://www.epa.gov/ region09/waste/sfund/prg. Accessed 12 Oct 2013.

U.S. Environmental Protection Agency (USEPA). (2005). Human health risk assessment protocol for hazardous waste combustion facilities. http://www.epa.gov/region6/6pd/rcra_c/ protocol/protocol.htm. Accessed 12 Oct 2013.

Wang, X. P., Shan, X. Q., Zhang, S. Z., \& Wen, B. (2004). A model for evaluation of the phytoavailability of trace elements to vegetables under the field conditions. Chemosphere, 55(6), 811-822.

Wang, X. L., Sato, T., Xing, B. S., \& Tao, S. (2005). Health risks of heavy metals to the general public in Tianjin, China via consumption of vegetables and fish. Science of the Total Environment, 350(1-3), 28-37.

Wang, A. S., Angle, J. S., Chaney, R. L., \& Delorme, T. A. (2006a). Soil pH effects on uptake of $\mathrm{Cd}$ and $\mathrm{Zn}$ by Thlaspi caerulescens. Plant and Soil, 281, 325-337.

Wang, G., Su, M. Y., Chen, Y. H., Lin, F. F., Luo, D., \& Gao, S. F. (2006b). Transfer characteristics of cadmium and lead from soil to the edible parts of six vegetable species in southeastern China. Environmental Pollution, 144(1), 127-135.

Wong, S. C., Li, X. D., Zhang, G., Qi, S. H., \& Min, Y. S. (2002). Heavy metals in agricultural soils of the Pearl River Delta, South China. Environmental Pollution, $119(1), 33-44$.

Wong, C. S. C., Li, X. D., Zhang, G., Qi, S. H., \& Peng, X. Z. (2003). Atmospheric deposition of heavy metals in the Pearl River Delta, China. Atmospheric Environment, 37(6), 767-776.

Yang, Q. W., Xu, Y., Liu, S. J., He, J. F., \& Long, F. Y. (2011). Concentration and potential health risk of heavy metals in market vegetables in Chongqing, China. Ecotoxicology And Environmental Safety, 74, 1664-1669.

Zeng, F. R., Ali, S., Zhang, H. T., Ouyang, Y. N., Qiu, B. Y., Wu, F. B., \& Zhang, G. P. (2011). The influence of $\mathrm{pH}$ and organic matter content in paddy soil on heavy metal availability and their uptake by rice plants. Environmental Pollution, 159, 84-91.

Zhang, M. K., \& Ke, Z. X. (2004). Heavy metals, phosphorus and some other elements in urban soils of Hangzhou City, China. Pedosphere, 14(2), 177-185.

Zhang, H. Z., Luo, Y. M., Song, J., Zhang, H. B., Xia, J. Q., \& Zhao, Q. G. (2011). Predicting As, Cd and $\mathrm{Pb}$ uptake by rice and vegetables using field data from China. Journal of Environmental Sciences, 23(1), 70-78.

Zhao, K. L., Zhang, W. W., Zhou, L., Liu, X. M., Xu, J. M., \& Huang, P. M. (2009). Modeling transfer of heavy metals in soil-rice system and their risk assessment in paddy fields. Environmental Earth Sciences, 59(3), 519527.

Zhao, H. R., Xia, B. C., Fan, C., Zhao, P., \& Shen, S. L. (2012). Human health risk from soil heavy metal contamination 
under different land uses near Dabaoshan mine, Southern China. Science of The Total Environment, 417-418, 4554.

Zheng, N., Wang, Q. C., \& Zheng, D. M. (2007). Health risk of $\mathrm{Hg}, \mathrm{Pb}, \mathrm{Cd}, \mathrm{Zn}$, and $\mathrm{Cu}$ to the inhabitants around Huludao zinc plant in China via consumption of vegetables. Science of The Total Environment, 383(1-3), 81-89.
Zhu, Y. G., Chen, B. D., Lin, A. J., Ye, Z. H., \& Huang, M. H. (2005). Heavy metal contamination in Pearl River Deltastatus and research priorities. Acta Scientiae Circumstantiae, 25(12), 1575-1579.

Zoller, W. H., Gladney, E. S., \& Duce, R. A. (1974). Atmospheric concentrations and sources of trace metals at the South Pole. Science, 183, 199-201. 